胸管リンパ球の機能からみたリンパ節郭清に対する一考察

\begin{tabular}{|c|c|c|c|c|c|c|}
\hline \multicolumn{7}{|c|}{ 藤田学園保健衛生大学第 2 病院外科 } \\
\hline 松本 & 純夫 & 永井 研治 & 杉本 & 辰雄 & 沓名 & 哲浩 \\
\hline 竹内 & 正 & 野本信之助 & 吉崎 & 聰 & & \\
\hline
\end{tabular}

\title{
A STUDY FOR REMOVAL OF LYMPH NODE IN VIEW OF THE FUNCTION OF THORACIC DUCT LYMPHOCYTES
}

\author{
Sumio MATSUMOTO, Kenji NAGAI, Tatsuo SUGIMOTO, \\ Tetsuji KUTSUNA, Tadashi TAKEUCHI, Shinnosuke NOMOTO \\ and Satoshi YOSHIZAKI
}

Department of Surgery, 2nd Teaching Hospital, School of Medicine Fujita Gakuen Health University

实引用䃁：胃癌リンパ節郭清, 胸管リンパ球, インターロイキン 2 (Interleukin 2: IL-2)

\section{緒 言}

消化器癌の治療において消化管付属リンパ節は癌の 進展形成の面から転移様式およびリンパの流れの面か らの研究は数多く行われてきた文2).その意味で転移り ンパ節の徹底的な郭清を行らことの重要性が従来から 強調されて来た。しかし消化管付属リンパ節における 局所免疫応答機序に関する検討は，抗腫場性の検討を 含めていまだ十分とは言えない，今回われわれは胸管 リンパ球の機能を抗腫場性の面から検討し，その結果 から消化管付属リンパ節の免疫応答能に関し若干の考 察をしたので報告する。

\section{対象およひ方法}

1972年から1984年までの当教室の初発胃癌症例は 353例でそのうちリンバ節転移に関し，十分に検索され た284例を対象として転移度,転移率などについて検討 した. 1982年以降, 上記症例のうちから再発の疑われ た 7 例および乳癌 1 例, 結核の 1 例（表 1 ）に胸管外 瘦を造設してリンパ球抒よびリンパ夜を採取し、リン パ球亜群, 細胞障害性などの面から末梢血リンパ球, 血清と比較検討し，一部はリンパ節とも比較検討を加 えた。

※第26回日消外総会シンポII：消化器癌リンパ節応答 とその郭清

$<1985$ 年11月12日受理 >別刷請求先：松本 純夫

₹454 名古屋市中川区尾頭橋 3-6-10 藤田学園

保健衛生大学第 2 病院外科
表 1 胸管外瘦造設症例

\begin{tabular}{|c|c|c|c|c|c|c|c|c|}
\hline 点 & 年些 & 性 & 竞名 & 啨期型 & 手简 & 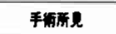 & $\lambda \overline{\boldsymbol{\gamma}} ー \ddot{シ}$ & 再竞形式 \\
\hline 1. K.I. & 35 & m & 用 & por & 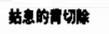 & $S_{2} P_{1} H_{0} N_{1}$ & 4 & 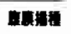 \\
\hline 2. A.N. & 54 & $f$ & 紫表 & - & 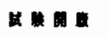 & $\mathrm{S}_{2} \mathrm{P}_{3} \mathrm{H}_{0} \mathrm{~N}_{2}$ & 4 & \\
\hline 3. S.M. & 65 & m & 觜 & tub 2 & 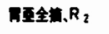 & $S_{2} P_{0} H_{0} N_{1}$ & 3 & リンバ简 \\
\hline 4. S.M. & 67 & $f$ & 西重 & tub? & 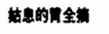 & $S_{2} P_{1} H_{0} N_{3}$ & 4 & If \\
\hline 5. H.O. & 42 & $f$ & 盟 & por & 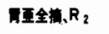 & $S_{2} P_{0} H_{0} N_{1}$ & 2 & リンバ笛 \\
\hline 6. S.T. & 74 & $f$ & 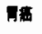 & tub $_{2}$ & 䙵全湴、 $R_{2}$ & $\mathrm{~S}_{2} \mathrm{P}_{0} \mathrm{H}_{0} \mathrm{~N}_{0}$ & 1 & - \\
\hline 7. H.S. & 71 & $f$ & mat & tub $_{1}$ & 同垔全湴、 $R_{2}$ & $S_{2} P_{0} H_{0} N_{2}$ & 1 & 所、早 \\
\hline 8. M.D. & 57 & $f$ & M: & med & 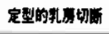 & $T_{2} N_{0} \quad M_{0}$ & 2 & リンハ敏? \\
\hline 9. M.S. & 78 & $\mathrm{~m}$ & 㰻楼 & - & - & $=$ & - & - \\
\hline
\end{tabular}

リンパ球严群の測定：Ortho 社製のモノクローナル 抗体 OKT3, 4, 6, 8, 9, 10, 11,. Ial, M1および Becton Dickinson 社製の Leu7, 11を用い, フローサイトメト リー法にしたがって分類した。

細胞障害性の判定: ${ }^{51} \mathrm{Cr}$ release assay 法により以 下の式から\%Lysis を求め比較検討した。

$$
\text { \%Lysis }=\frac{\text { Exp. cpm }- \text { spont. cpm }}{\text { Max. cpm }- \text { spont. cpm }} \times 100
$$

標的細胞として下記の 3 種の継代培養細胞株を用い た. K562（ヒト急性骨髄性白血病由来培養株, NK 感 受性), PLC (ヒト肝細胞癌由来培塏株, NK 非感受 性), KATO-3 (ヒト胃癌由来培養株, NK 非感受性).

胸管外瘦：左鎖骨上窩に局所麻醉下でリンパ節生検 を行うとともに胸管を露出しアトム多用途チューブを 挿入し胸管リンバ夜を採取した。通常は中心静脈栄養 カテーテルとチューブを連結し外シャントを作りリン 
パ液の喪夫を防止し，必要な時だけ採取することにし ている.

培養液：RPMI1640に0.5mM 可久了ミノ酸, $5 \mathrm{mM}$ ピルビン酸ナトリウム, $5 \times 10^{-5} \mathrm{M} 2$-メルカプトェタ ノール, $2 \mathrm{mM}$ L-グルタミン, $100 \mu \mathrm{g} / \mathrm{ml}$ ストレブトマ イシン (M.A. Bioproducts 社製)，100U/ml ペニシリ V(Flow 社製), 25mM HEPES, $10 \% \mathrm{FCS}$ (M.A Bioproducts 社製）を添加して 37 度， $5 \% \mathrm{CO}_{2} 100 \%$ 加 湿下に培養を行った.

リンパ球の分離：末梢血をーパリン採血した後，比 重遠沈法によりリンパ球を分離し、リン酸緩衝液にて 3 回洗浄して使用した。胸管リンパ球も同用の方法で 分離使用した。

IL-2：末梢血リンパ球の $10^{6} / \mathrm{ml}$ を $1 \% \mathrm{PHA} ， 10 \%$ FCS 加 RPMI1640中で48時間培養後，その上清をT細 胞増殖因子として粗 Interleukin 2 (IL-2) と呼び使用 した。また一部には塩野義製薬製のリコンビナント IL-2む使用した。

胃癌手術に拈いて R2のリンパ節郭清施行するとリ ンパ節の切除ととすに胸管への経路である腹腔動脈周 囲リンパ管経路の遮断されることとなり，本来胸管へ 流入するはずのリンパ球の道筋す遮断され，一部はド レーンを通して体外へ排出されることとなる，その影 響をみるために手術前, 術後 1 週目, 3 週目に血液像, リンパ球亜群の変化を検討した。

\section{成 結}

胸管リンパ球の亜群と胸管リンパ液の性状：胸管リ ンパ球はその70から80\%が OKT3もしくは OKT11陽 性細胞であり，B細胞成分は非常に少なかった．末梢 血リンパ球に比べて OKT4陽性細胞が多く，OKT8陽 性細胞が少なく（p<0.01）また OKM1, Leu7, Leu11 が末梢血リンパ球に比べ極端に少なかった（p<0.05） (図 1 ). 胸管リンパ液には赤血球成分は洼とんぞなく

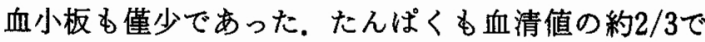
あった。電解質ではカリウムが血清値よりも低值であ

図 1 末梢血リンパ球と胸管リンパ球の亜群の比較

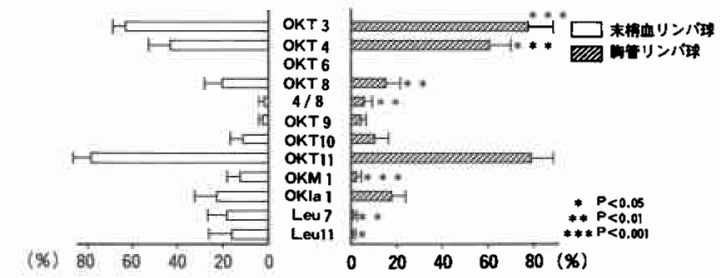

り, LDH, コレステロール, IgA も有意の差をるって 低値であった(表 2 ). ウイルヒョウリンパ節の亜群を みると B 細胞成分と思われる OKIa1陽性細胞が多く なり構成細胞の比率は胸管リンパ球と末梢血リンパ球 の中間であった。

胸管リンパ球の細胞障害性：細胞障害性を末梢血り ンパ球と比較すると，末梢血リンパ球はLeu11が約 20\%を占めることを反映して K562を標的細胞とした 場合 $\mathrm{E} ： \mathrm{~T}, 100 ： 1$ で60\%以上の細胞障害性を示すの に対し，胸管リンパ球は採取直後では約 $20 \%$ の細胞障 害性しか示さなかった，しかし IL-2, 100U/ml 添加， 4 日間培養後では胸管リンパ球は $40 \%$ 前後の細胞障害 性を示すようになった. NK 非感受性の PLCを標的細 胞とした場合，末梢血リンパ球は $10 \%$ 前後の細胞障害 性であり，胸管リンパ球も無処置では何の細胞障害性 も示さなかった，しかし IL-2を添加培養すると E：T，

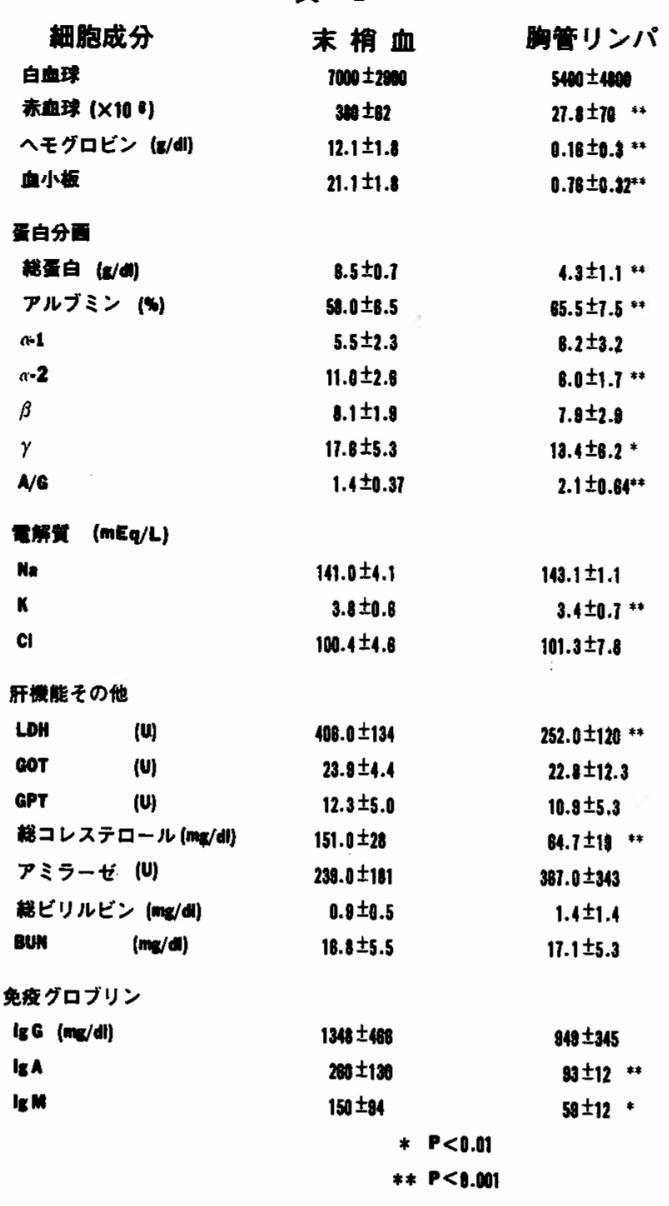


50：1では10\%以上の細胞障害性を示すようになった (図 2).この培養前後での胸管リンパ球の亜群の変化 をみるとほとんどすべての亜群が増加しているが, 特 にOKT8, 9, 10, M1, Ia1拈よび Leu11の增加が著明で あった（図 3 ).

術前術後での血液像の変化をみるとステージ別の差 異はほとんどなく白血球は減少傾向にあった。 小リン 公球は術後 1 週目には減少したが 3 週目には術前値に 復した. 大リンパ球, 単球には变化を認めなかった(図
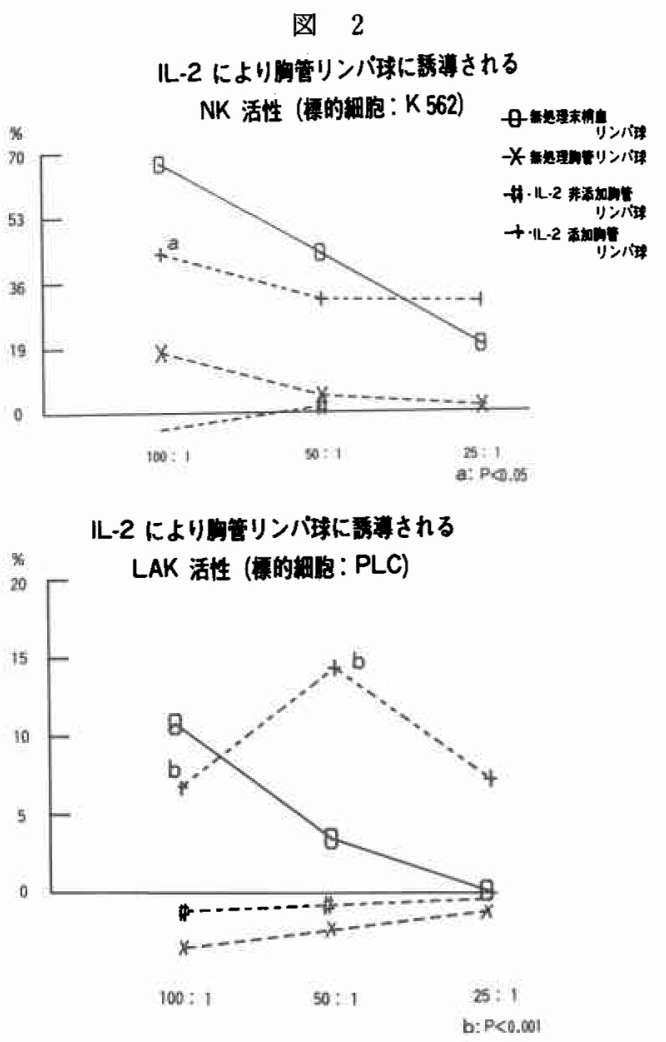

圀 3 IL-2添加培養前後での胸管リンパ球互群の比較

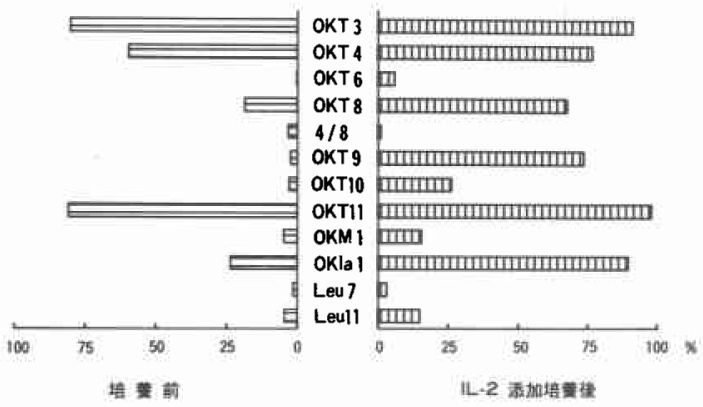

図4 胃癌リンパ節郭清前後でのリンパ球の変化

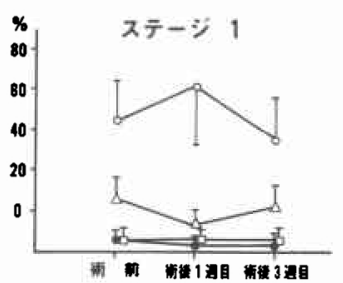

○白自球 $* 10^{2} / \mathrm{m}^{2}$

・ 大リンバ (\$)

ロホリンバ球 (\%)

口辛
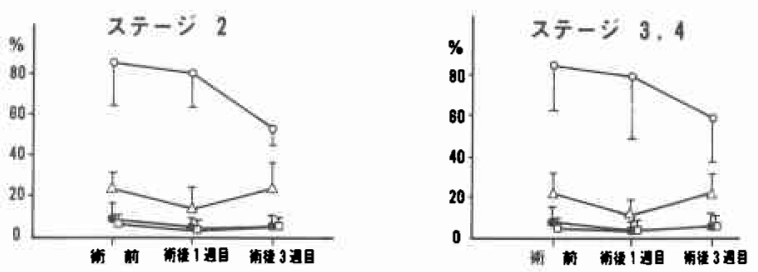

図 5 早期胃癌の $\mathrm{R}_{2}$ リンパ節郭清による末梢血リン パ球亜群に及ぼす影響

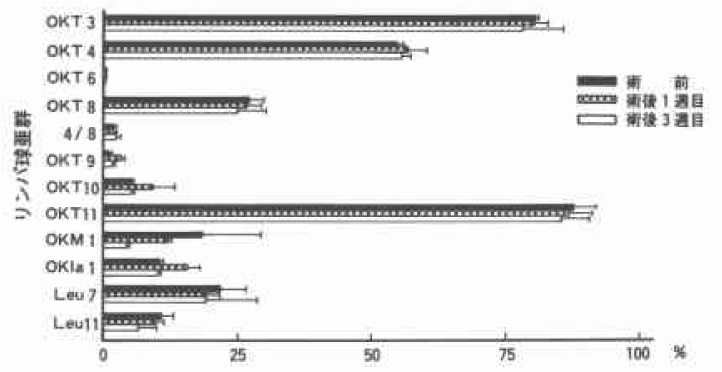

4 ). 形態的には顕著な変化はなかったが，モノクロー ナル抗体による亜群の変化でみるとOKM1と Leu11 が早期胃癌では術前値に比べ術後 1 週目, 3 週目と減 少する傾向にあった，進行胃癌ではそのような傾向は 認めなかった（図５）。

\section{考察}

消化管上皮で癌が発生する以上, 何らかの免疫応答 がその場で行われていると考穴るのは当然である。そ の意味で癌先進部でのリンパ球浸潤あるいはリンパ節 の sinus histio cytosis (SH) が従来から問題にされ予 後との相関が論じられ, リンパ球漫潤の強いものの予 後が良いとされて来た ${ }^{3)}$.しかしこれらの報告はすべ て組織学的, 形態学的な見地からのるので, 細胞レへ ルでの機能までは追求されていないのが現状であっ た.

消化管に付随するリンパ装置のなかで胸管は主とし て横隔膜下の消化管および肝臟を主体とした実質臟器 
のリンパ液を集めて大循環へ流入する経路となる，胸 管を流れるリンパ液, リンパ球は消化管あるいは消化 管付属リンパ節で行われた免疫応答の何らかの情報を 担っていると考兄られる。事実，胸管リンパ液中には 腫湯細胞が認められることがあり，その周囲にリンパ 球を接着している像がみられることすある(1).胸管リ ンパ球の亜群分布をみるとほとんどT細胞で末梢血に 比べへルパー/インデューサーとされるOKT4の占め る割合が高く、マクロファージとされる OKM1, NK あるいはKとされるLeu7, NK とされるLeu11が非常 に少なく，末梢血とばかりでなくリンパ節とも亜群の 構成は異なり独特の役割を有すると考学られる 管リンパ球の細胞障害性を調べてみると，無処理では NK 感受性, 非感受性の標的細胞の何れに対しても細 胞障害性を示さないが，粗 IL-2，リコンビナント IL-2 を添加培養した場合は，いずれの場合でる細胞障害性 の著明な上昇を認めた。この結果は胸管リンパ球から NK および Lymphokine activated killer (LAK) が 誘導されたことを示し，胸管リンパ球は LAK の前駆 細胞であると言う Grim ら ${ }^{6}$ の報告と一致した結果で ある. LAK は自己の新鮮固形腫場を破壊することが できるとされ，ヒトの固形腫痬に対しても応用が出来 るのではないかと考兄られている。比担癌状態 がかなり進行しても IL-2産生能は保たれているとさ れ，再発が疑われたり，もしくは確定している患者で も胸管リンパ球から LAK あるいは NK が誘導される ことをわれわれのデーターは示している，LAKは OKT3, 8陽性とされ，NKは Leu7あるいは Leu11陽性 とされている。これらの前駆細胞がリンパ節郭清と術 後ドレーンからのリンパ液の漏出とともに岥失されれ ば末梢血リンパ球の亜群分布に変化が起こるであろら と考光検討したところ，早期胃癌においてだけ Leu11, Leu7, OKM1, OKT8が術前に比べ術後第 3 週をで減 少していた。進行胃癌ではむしろ術後Leu11, OKT8, OKM1が上昇する例もあった。この結果の意味すると ころは, 進行胃癌では癌を除去することが免疫応答能 を回復させ, リンパ節郭清も転移しているものを切除 している可能性が高いので生体にとって有益である が，早期胃癌ではリンパ節郭清がかえって生体の防御
機能を減弱させていることにつながるのではないかと 考えている。

このような観点から当教室の胃癌リンパ節転移率を 見直す之, 深達度 $m$ 癌33例中 1 例 $(3 \%), \mathrm{sm}$ 癌 38 例中 4 例 (10.5\%) の転移陽性例の扱いが考慮されなけれ ばならない。この内 2 例は $\mathrm{n} 1(-), \mathrm{n} 2(+)$ の跳躍転 移例も含まれており, 現在は術前および術中にリンパ 節転移の有無を識別出来る確実な万法が無い以上, 特 異的, 非特異的免疫応答能を弱める結果になったとし ても R2の郭清が望ましいと考兄ており,リンパ節転移 に関しては症例毎の細かな対応が免疫応答能の保持に は必要と考克ている。

\section{結 語}

1. 胸管リンバ球は NK および LAKの前駆細胞を ふくんでいる。

2. 早期胃癌に R2のリンパ節郭清を行らと術後 3 週 までの追跡では末梢血リンパ球中の OKT8, OKM1， Leu7, Leu11の比率は低下傾向にあった。

3. 進行胃癌においてはリンパ節郭清前後での末梢 血リンパ球亜群変化に一定の傾向を認めなかった。

\section{文献}

1）宮本徳廣, 小川道雄, 岡川和弘ほか：早期胃癌およ び早期胃癌類似進行癌の組織型とそのその臨床病 理学的特徵一とくに転移とリンパ管侵襲一。日消 外会誌 $16: 1772-1777,1983$

2）佐々木迪郎, 市川健寛, 宮川 明ほか：早期胃癌の リンパ節郭清と手術成績. 日臨外医会誌 43 ： $642-650,1982$

3）大森幸夫：胃癌におけるリンパ球浸潤. 外科 $42: 881-885,1980$

4）吉䓫 聰, 笠原正男 : 特集リンパと外科, 胸管リン パにるる胃癌診断及び治療上の意義. 外科診療 24 : 1797-1808, 1982

5）松本純夫, 永井研治, 野本信之助ほか：ヒト胸管リ ンパ球のサブポピュレーションについて，リンパ 学 7:113-115, 1984

6) Grim EA, Mazumder A, Rosenberg SA : Lymphokine-activated killer resistant fresh solid tumor cells by interleukin 2-activated autologous human peripheral blood lymphocytes. J Exp Med 155 : 1823-1841, 1982 